\title{
Molecular Detection and Clinical Characteristics of Bacterial and Viral Main Etiological Agents Causing Respiratory Tract Infections in Tehran, Iran
}

Taher Azimi Sarikhanbaghloo

Aja University of Medical Sciences

Ramin Hamidi-Farahani

Aja University of Medical Sciences

Ali Asgari

Aja University of Medical Sciences

Jalil Rajabi

Aja University of Medical Sciences

Mousa Ahmadi

Aja University of Medical Sciences

Mohammad Darvishi

Aja University of Medical Sciences

Mohammad Aminianfar

Aja University of Medical Sciences

Saeed Soleiman-Meigooni ( $\sim$ Dr.saeed.meigooni@gmail.com )

Aja University of Medical Sciences

Research Article

Keywords: COVID-19, coronavirus disease, respiratory tract infection, viral infection, bacterial infection, military personals

Posted Date: March 15th, 2021

DOI: https://doi.org/10.21203/rs.3.rs-279011/v1

License: () (1) This work is licensed under a Creative Commons Attribution 4.0 International License. Read Full License 


\section{Abstract}

Background: Respiratory tract infections are one of the most important infections among military personals, worldwide. The present study aimed to survey the prevalence of bacterial and viral main etiological agents causing respiratory tract infections among the military personnel in Iran. A crosssectional study was performed from September 2020 to February 2021. Nasopharyngeal swabs were taken from patients, military personnel with respiratory tract infection symptoms. Detection of COVID-19 was performed with one step qRT-PCR method. TaqMan probe-based real-time PCR assay was used for the detection of influenza A and B viruses. The prevalence of adenovirus and M. pneumoniae were determined using nested PCR. Moreover, B. pertussis and S. pyogenes were identified by conventional PCR assay. The detection of $H$. influenzae was performed by multiplex PCR method.

Results: Overall, 145 patients were included. Among viral pathogens, COVID-19, influenza A virus, and adenovirus were identified in $85.5 \%, 4.1 \%$, and $1.4 \%$ of patients, respectively. Influenza B virus was not detected among military personnel. The frequency of bacteria etiological agents was as follows: S. pyogenes (2\%), M. pneumoniae (0.7\%), H. influenzae (0\%), and B. pertussis (0\%). Muscle aches (75.9\%), headache (70.3\%), lethargy (69\%), cough (66.2\%), stuffy nose (56.6\%), fever (53.8\%), and sore throat (53.1\%) were amongst the most common clinical symptoms.

Conclusions: Results showed that the military personals are the susceptible group to COVID-19 infection. Therefore, the accurate detection and implementation of control strategies such as vaccination are necessary.

\section{Introduction}

Globally, respiratory tract infections are one of the most important infections among the most common infectious diseases[1]. Respiratory tract infections were considered life-threatening complications that can cause high morbidity and mortality in both adults and children[2]. Respiratory tract infections can be caused by different classes of etiologic agents and are usually separated into two main groups including lower respiratory tract infections and upper respiratory tract infections[3]. Several groups of pathogens such as bacteria and viruses cause the highest proportion of respiratory tract infections. Among bacterial pathogens, respiratory tract infections can be caused by Haemophilus influenzae (H. influenzae), Streptococcus pneumoniae (S. pneumoniae), Bordetella pertussis (B. pertussis), Chlamydia pneumoniae (C. pneumoniae), Streptococcus pyogenes (S. pyogenes), and Mycoplasma pneumoniae (M. pneumoniae)[4-6]. However, most cases of respiratory tract infections are caused by viruses, and these agents are responsible for a large proportion of human upper respiratory tract infections[7]. Well-diagnosed viral pathogens which can cause a variety of respiratory disease are influenza A and B viruses, adenovirus, respiratory syncytial virus, parainfluenza, metapneumovirus, enterovirus, rhinovirus, and coronavirus[8]. World Health Organization (WHO) considered coronavirus disease 2019 (COVID-19) a public health emergency of international concern[9]. This new virus has caused significant mortality and morbidity, globally[10]. Till 08/February/2021 around 106,696,325 cases of COVID-19 and 2,327,535 deaths have been reported, worldwide (https://www.worldometers.info/coronavirus/?utm_campaign=homeAdUOA?Si). To date, COVID19 causing >1,466,435 confirmed cases and over $>58,469$ deaths in Iran and there are no effective antiviral drugs or specific vaccines against COVID-19 (https://www.worldometers.info/coronavirus/country/iran/). In general, viruses created similar and nearly indistinguishable clinical signs and symptoms to bacterial pathogens in patients[11]. Moreover, in most cases, physicians prescribe different antibiotics without any laboratory testing for the treatment of respiratory infections[1]. The unnecessarily prescribed antibiotics lead to the emergence of antimicrobial resistance among pathogens. Consequently, in the diagnosis of causative pathogenic agents, clinical findings alone are not reliable and laboratory confirmation is necessary to definitively identify aetiological agents of respiratory infections[12]. Globally, due to several conditions such as insomnia, stressful working environment, demanding physical training programs, and crowded habitation, military populations are more susceptible to respiratory infections, and each year during the autumn and winter seasons, numerous cases of respiratory infections happen among military populations[13,14]. However, only a few data are available on the role of bacterial and viral pathogens in the etiology of respiratory tract infections in military populations in Iran. Hence, this study was performed to investigate the main bacterial and viruses among the military personnel presenting with symptoms and clinical signs of acute respiratory disease in Iran.

\section{Materials And Methods}

\section{Study design and sample collection}

This cross-sectional study was conducted at AJA University of Medical Sciences from September 2020 to February 2021. Patients presenting different symptoms and clinical signs of respiratory tract infection were included in this study. All participants provided written informed consent before enrolment. After informed consent, sociodemographic data and clinical signs including age, height, weight, blood type, types and times of facemasks used during COVID-19 pandemic, a history of high blood pressure, a history of lung diseases such as chronic obstructive pulmonary disease (COPD), a history of asthma disease, obesity, irritable bowel syndrome (IBS), diabetes, a history of the liver disease (fatty liver disease), contact with a person who has a positive test to COVID-19, alcohol consumption, smoking, fever, chills, cough, muscle aches, lethargy, red eyes, diarrhea, vomiting, nausea, runny or stuffy nose, gastrointestinal bleeding, sore throat, chest pain, headache, dyspnea, changes the sense of smell and taste, loss of consciousness, and joint pain were recorded. The samples were collected by the nasopharyngeal swabs (flock swabs, Copan, Italy) in $10 \mathrm{ml}$ of sterile phosphate-buffered saline (PBS, 0.1M, pH 7.2) and were transported to the Comprehensive Research Laboratory, School of Medicine, AJA University of Medical Sciences. The three nasopharyngeal swab samples were taken from each included patient.

DNA extraction and detection of bacterial respiratory pathogen 
The first nasopharyngeal swabs were placed in $1 \mathrm{ml}$ of sterile saline and mixed by vigorous vortex for 30 to $45 \mathrm{~s}$. At the next step, swabs were removed from samples and saline suspensions were transferred to a $1.5 \mathrm{ml}$ Eppendorf tube. The Eppendorf tubes were centrifuged at $13000 \mathrm{rpm}$ for $5 \mathrm{~min}$ and pellet suspended in $300 \mu \mathrm{l} 20 \%$ Chelex in TE buffer and then heated at $95^{\circ} \mathrm{C}$ for $5 \mathrm{~min}$ to disrupt the cells. All samples were stored at $-20^{\circ} \mathrm{C}$. For the detection of $B$. pertussis, the specific primers which targeted the $I S 481$ gene were used. The primer sequence used for the detection of $B$. pertussis were as follows: PIp1-F: 5'-CCCATAAGCATGCCCGATTGAC-3' and PIp2-R: 5'-CGCACAGTCGGCGCGGTGAC -3'. The PCR assay was carried out in a total volume of $50 \mu \mathrm{l}$ reaction containing $5 \mathrm{mM} \mathrm{MgCl} 2,6 \mu \mathrm{l}$ of 10x PCR buffer, $1 \mu \mathrm{M}$ of each forward (Pip1) and reverse (Pip2) primers (10mM), 2 units of Taq polymerase (Cinnagene, Iran), $1 \mu \mathrm{l}$ of $10 \mathrm{mM}$ of each deoxynucleoside triphosphate (dNTPs), $10 \mathrm{ml}$ of the stored clinical sample and sterile distilled water up to $50 \mu \mathrm{l}$. The PCR reaction condition and parameters were similar to those described by Brandberg et al[15].

To detection of M. pneumoniae, swab samples were placed in microtubes containing phosphate-buffered saline (PBS), and then DNA extraction was conducted using a MagNa Pure LC DNA I isolation kit (Roche Diagnostics GmbH, Mannheim, Germany) according to the manufacturer's guidelines. The semi-nested PCR method was used to screen the presence of $M$. pneumoniae in the swab samples. Briefly, M. pneumoniae DNA was amplified and detected using the first-round primer pairs including 5'-TGCCATCAACCCGCGCTTAAC-3' and 5'-CCTTTGCAACTGCTCATAGTA-3' and the second-round primers including 5'- CCTTTGCAACTGCTCATAGTA -3 ' and 5'-CAAACCGGGCAGATCACCTTT-3'. The semi-nested PCR conditions and parameters were set based on a previously published study by Nilsson et al[16].

The detection of $S$. pyogenes was performed with the PCR method and using specific primer pairs including F: 5'-AAAGACCGCCTTAACCACCT- 3' and R: 5'-TGGCAAGGTAAACTTCTAAAGCA-3' target the spy1258 gene. PCR was conducted in a total volume of $25 \mu \mathrm{l}$ reaction including $3 \mu \mathrm{l}$ of $10 \times$ PCR buffer without $\mathrm{MgCl} 2,2.5 \mathrm{mmol} / \mathrm{I} \mathrm{MgCl} 2,0.5 \mu \mathrm{l}$ of $10 \mathrm{mM}$ of each deoxynucleoside triphosphate (dNTPs), $0.5 \mu \mathrm{M}$ of each primer (10 mM), 1 unit of Taq polymerase (Cinnagene, Iran), $5 \mu \mathrm{l}$ of template DNA, and $5.5 \mu \mathrm{l}$ of sterile distilled water. PCR program of spy 1258 gene is followed by initial denaturation for $2 \min$ at $94{ }^{\circ} \mathrm{C}, 35$ cycles of denaturation for $35 \mathrm{~s}$ at $94{ }^{\circ} \mathrm{C}$, annealing for the $20 \mathrm{~s}$ at $55^{\circ} \mathrm{C}$, elongation for $40 \mathrm{~s}$ at $72{ }^{\circ} \mathrm{C}$, and final elongation for $2 \mathrm{~min}$ at $72{ }^{\circ} \mathrm{C}$.

For $H$. influenzae detection, the multiplex PCR method target genes HiP6 and bexA were used. The primers sequences were as follows: HiP6-F: ACTTTTGGCGGTTACTCTGT and HiP6-R: TGTGCCTAATTTACCAGCAT, bexA-142-F: GGCGAAATGGTGCTGGTAA and bexA-241-R: GGCCAAGAGATACTCATAGAACGTT. PCR was performed on Eppendorf Mastercycler EP thermocycler and PCR programs are followed by initial denaturation for 5 min at $94{ }^{\circ} \mathrm{C}$, with 35 cycles of $95^{\circ} \mathrm{C}$ for $30 \mathrm{~s}$, annealing for the $60 \mathrm{~s}$ at $50{ }^{\circ} \mathrm{C}$, an extension for 1 min at $72{ }^{\circ} \mathrm{C}$, and final extension for $10 \mathrm{~min}$ at $72{ }^{\circ} \mathrm{C}$. Finally, all PCR products were electrophoresed and screened on a 1-1.5\% agarose gel, and then stained with DNA-safe stain (SinaClon, Tehran, Iran). PCR products were visualized by a UV transilluminator and photographed under UV light.

\section{RNA extraction and complementary DNA synthesis}

Total viral RNA was extracted from $200 \mu$ l of nasopharyngeal swab samples using the QIAamp Viral RNA Mini kit (Qiagen, Mississauga, Ontario, Canada) according to the supplier's instructions. To remove any genomic DNA carryover, 20 U of RQ1 RNAse-free DNAse (Promega, Madison, WI, USA) was used and then extraction was suspended in $50 \mu$ l of diethyl pyrocarbonate-treated water $(0.1 \% \mathrm{v} / \mathrm{v})$. The complementary DNA synthesis was performed using the RevertAid First Strand cDNA Synthesis Kit (Fermentas, ON, Canada). Synthesis conditions have been described by Maclntyre et al[6].

\section{Detection of viral respiratory pathogens}

Nested PCR was used for detecting adenoviruses using specific primer pairs. In brief, adenoviruses DNA was amplified and detected using the firstround primer pairs including 5'-GCCGCAGTGGTCTTACATGCACATC-3' and 5'-CAGCACGCCGCGGATGTCAAAGT -3' and the second-round primers including 5'-GCCACCGAGACGTACTTCAGCCTG-3' and 5'-TTGTACGAGTACGCGGTATCCTCGCGGTC-3'. PCR conditions were set based on a previously published study by Rigotto et al[17]. PCR reactions were conducted under the following condition: initial denaturation at $95^{\circ} \mathrm{C}$ for 5 min followed by 40 cycles at $95^{\circ} \mathrm{C}$ for $1 \mathrm{~min}$, annealing at $56^{\circ} \mathrm{C}$ for $1 \mathrm{~min}$, and $72^{\circ} \mathrm{C}$ for $45 \mathrm{~s}$ with the final incubation at $72{ }^{\circ} \mathrm{C}$ for $7 \mathrm{~min}$.

The probe-based real-time PCR was used to detection of influenza A and B viruses. For detection of influenza A and B viruses in nasopharyngeal swab samples, the primes and probes target the matrix protein (M) and hemagglutinin gene segment (HA) genes, respectively. Complementary DNA was amplified using the following primer and probe: M-F: 5'- GGACTGCAGCGTAGACGCTT-3', M-R: 5'- CATCCTGTTGTATATGAGGCCCAT-3', probe: 5'-FAMCTCAGTTATTCTGCTGGTGCACTTGCCA-TAMRA-3', and HA-F: 5'-AAATACGGTGGATTAAATAAAAGCAA-3', HA-R: 5'-CCAGCAATAGCTCCGAAGAAA-3', probe: 5'-FAM-ACCCATATTGGGCAATTTCCTATGGC-TAMRA-3'. Real-time PCR conditions were set based on a previously published study by Elden et al[18]. In summary, the reaction was performed with the final volume of $25 \mu$ including $12.5 \mathrm{ml}$ of TaqMan Universal PCR master mix containing ROX as a passive reference (PE Applied Biosystems), $5 \mu \mathrm{l}$ of cDNA, $1 \mu$ l of each influenza virus A and B primers, $100 \mathrm{nM}$ each probe, and sterile distilled water up to $25 \mu \mathrm{l}$. The real-time PCR was conducted on a Corbett 6000 Rotor-Gene thermocycler (Corbett Research) under the following conditions: $50^{\circ} \mathrm{C}$ for $2 \mathrm{~min}$ (optimal AmpErase Uracil-N-glycosylase activity) followed by of $95^{\circ} \mathrm{C}$ for $10 \mathrm{~min}, 45$ cycles of $95^{\circ} \mathrm{C}$ for $20 \mathrm{~s}$ and of $60{ }^{\circ} \mathrm{C}$ for 1 min. During amplification procedures, the fluorescence radiating from the used probes was documented.

\section{Detection of COVID-19 by One-Step Quantitative RT-PCR System}


Detection of COVID 19 was performed with one step qRT-PCR method. For this purpose, the primers and probes target the RdRp genes (nCoV_IP2 and nCoV_IP4). The primers and probes sequence used for the detection of viral RNA were as follows: nCoV-IP2-F: 5'-ATGAGCTTAGTCCTGTTG-3', nCoV-IP2R: 5'-CTCCCTTTGTTGTGTTGT-3', nCoV-IP2-12696bProbe: 5'-Hex-AGATGTCTTGTGCTGCCGGTA-3'-BHQ-1 and nCoV-IP4-F-5'-

GGTAACTGGTATGATTTCG-3', nCoV-IP4-F-5'-CTGGTCAAGGTTAATATAGG-3', nCoV-IP4-14084Probe: 5'-Fam-TCATACAAACCACGCCAGG-3'-BHQ-1. Moreover, we used RNase P (C1), labeled with BHQ-1 and HEX fluorescent dye as an internal reference control. Quantitative RT-PCR was performed with a Kit Extraction NucleoSpin Dx Virus (Macherey Nagel ref. 740895.50) and Invitrogen Superscript ${ }^{\text {TM }}$ III Platinum® One-Step qRT-PCR system (ref: 11732088). The optimized concentrations were performed in a total volume of $25 \mu$ reaction including $3.6 \mu$ sterile distilled water, $12.5 \mu$ l Reaction mix $2 X$ (3 $\mathrm{mM} \mathrm{Mg}), 0.4 \mu \mathrm{l} \mathrm{MgSO} 4(50 \mathrm{mM}), 1 \mu \mathrm{l}$ of each primer $(10 \mathrm{mM}), 0.5 \mu \mathrm{l}$ of Probes $(10 \mu \mathrm{M}), 1 \mu \mathrm{l}$ superscriptlll RT/Platinum Taq Mix, and $5 \mu \mathrm{l}$ of extracted RNA sample. Amplification condition was as follows: reverse transcription for 20 min at $55^{\circ} \mathrm{C}$, denaturation for 3 min at $95^{\circ} \mathrm{C}, 50$ cycles of denaturation for $15 \mathrm{~s}$ at $95^{\circ} \mathrm{C}$, annealing for the $30 \mathrm{~s}$ at $58^{\circ} \mathrm{C}$, and cooling for $30 \mathrm{~s}$ at $40^{\circ} \mathrm{C}$. Cycle threshold (CT) value equal to or less than 30 was considered to be positive.

\section{Statistical Analysis}

All sociodemographic and clinical data of patients were formatted in an SPSS file, and the data were analyzed by the statistical package SPSS v.23.0 (SPSS Inc., Chicago, IL, USA) using descriptive statistic tests.

\section{Results}

\section{Study Population}

In the current study, a total of 145 patients who were referred to Imam Reza Hospital, AJA University of Medical Sciences, were selected based on their clinical signs and symptoms of respiratory tract infections. Demographic information and clinical signs of these patients are summarized in Table 1. The age of the patients ranged from 19 to 55 years, with a mean age of $26 \pm 0.5$ years. Among the studied participants, $55.9 \%(n=81 / 145)$ and $20 \%$ ( $=29 / 145$ ) were in the age range of 18 to 25 years and $>=36$ years, respectively. The mean weight of the patients was $78 \pm 0.2 \mathrm{Kg}$ and the weight of the patients ranged from 50 to $125 \mathrm{Kg}$. The body mass index (BMI) was 18.5 to 24.9 and 25 to 29.9 in $49 \%$ and $39.2 \%$ of patients, respectively. The frequency of different blood groups among patients were as follows: $O^{+}(43.4 \% ; 63 / 145), O^{-}(2.1 \% ; 3 / 145), A^{+}(27.6 \% ; 40 / 145), A^{-}(2.1 \% ; 3 / 145), B^{+}$ (14.5\%; 21/145), $B^{-}(2.8 \% ; 4 / 145), A B^{+}(7.6 \% ; 11 / 145)$, and blood group $A^{-}(0 \% ; 0 / 145)$. Based on the self-declaration, $71.7 \%(n=104 / 145)$ of patients used facemasks at all times during COVID-19 pandemic and $6.2 \%(n=9 / 145)$ of patients rarely used facemasks. Moreover, $84.8 \%(n=123 / 145)$ and $11.7 \%(n=17 / 145)$ of patients were used cloth and surgery facemasks, respectively. $3.4 \%(5 / 145)$ of patients only used N95 or FFP2 facemasks. Out of 145 included patients, 32.4\% (47/145) were smokers and $13.1 \%(n=19 / 145)$ have a history of alcohol consumption. The frequency of underlying diseases among patients were as follows: high blood pressure (11.7\%; $n=17 / 145)$, fatty liver disease $(13.8 \% ; n=20 / 145)$, IBS $(6.9 \% ; n=10 / 145)$, asthma $(6.9 \% ; n=10 / 145)$, COPD $(4.8 \% ; n=7 / 145)$, and diabetes $(2.1 \% ; n=3 / 145)$. In general, $79.3 \%(n=115 / 145)$ of patients had a history of close contact with COVID positive person in the military medical center, military hospitals, military sanatoria, or community. The main important clinical signs and symptoms among included patients were muscle aches $(75.9 \% ; n=110 / 145)$, headache $(70.3 \% ; n=102 / 145)$, lethargy $(69 \%$; $n=100 / 145)$, cough $(66.2 \% ; n=96 / 145)$, stuffy nose $(56.6 \% ; n=82 / 145)$, fever $(53.8 \% ; n=78 / 145)$, and sore throat $(53.1 \% ; n=77 / 145)$, respectively.

\section{Detection and clinical signs of bacterial pathogens}

In total, the frequency of main bacterial pathogens including $H$. influenzae and $B$. pertussis, $M$. pneumoniae, and $S$. pyogenes was surveyed among the military soldiers with acute respiratory disease. The bacterial pathogens detection rates are summarized in Table 1. Overall, respiratory bacterial pathogens were detected in 4 of $145(2.75 \%)$ included patients. $H$. influenzae and B. pertussis was not detected among military soldiers with acute respiratory disease. S. pyogenes and M. pneumoniae were found in $2 \%(n=3 / 145)$ and $0.7 \%(n=1 / 145)$ of the patients. The $M$. pneumoniae was detected in patients 18 to 25 years old $(n=1 / 85 ; 1.25 \%)$. The one patient who was positive for M. pneumoniae had a BMI >40, blood group B-and a history of close contact with a COVID positive person. Moreover, this patient has used a surgical facemask at all times during COVID-19 pandemic and showed several clinical symptoms such as chest pain, muscle aches, and headache. On the other hand, S. pyogenes was found among patients 18 to 25 years old $(n=3 / 85 ; 3.7 \%)$. Moreover, $5.6 \%(n=1 / 18)$ of patients with BMI 30 to 34.9 were positive for S. pyogenes. All 3 patients who were positive for $S$. pyogenes had the blood group $\mathrm{O}^{+}$and a history of close contact with a COVID positive person. The frequency of $S$. pyogenes among patients that used cloth and surgical facemasks was $5.9 \%(n=1 / 17)$ and $1.6 \%(n=2 / 123)$, respectively. The main clinical symptoms among patients with $S$. pyogenes infection were chest pain $(100 \% ; n=3 / 3)$, cough $(66.6 \% ; n=2 / 3)$, lethargy $(66.6 \% ; n=2 / 3)$, muscle aches $(66.6 \%$; $n=2 / 3)$, and fever $(66.6 \%$; $n=2 / 3)$.

\section{Prevalence and clinical signs of COVID-19}

The number of samples found by One-Step Quantitative RT-PCR to be positive for COVID-19 was 124/145 (85.5\%). Among different age groups, the highest prevalence of COVID-19 was seen in the patients $\geq 36$ years old ( $n=28 / 29 ; 96.5 \%), 26$ to 30 years old $(n=23 / 24 ; 95.8 \%$ ), and 31 to 35 years old $(n=10 / 11 ; 90.1 \%)$, respectively. Moreover, the highest frequency of COVID-19 was detected among patients with BMI 30 to 34.9 ( $n=17 / 18 ; 94.5 \%$ ), 25 to $29.9(46 / 51 ; 88.2 \%)$, and 18.5 to $24.9(n=59 / 71 ; 83 \%)$, respectively. The frequency of COVID-19 among different blood groups was as follows: $0^{+}$ $(n=51 / 63 ; 81 \%), O^{-}(n=3 / 3 ; 100 \%), A^{+}(n=35 / 40 ; 87.5 \%), A^{-}(n=3 / 3 ; 100 \%), B^{+}(n=20 / 21 ; 95.2 \%), B^{-}(n=3 / 4 ; 75 \%), A B^{+}(n=9 / 11 ; 82 \%)$. 
In total, 79\% ( $n=98 / 124)$ of patients with COVID-19 infection had a history of close contact with COVID positive person. Results showed that out of 124 patients with COVID-19 infection, 106 patients (85.5\%) used surgical facemasks during COVID-19 pandemic and 90 patients (72.6\%) used facemasks at all times. Moreover, out of 124 patients with COVID-19 infection, 33\% ( $n=41 / 124)$ were smokers and 14.5\% ( $n=18 / 124)$ have a history of alcohol consumption. The frequency of underlying disease among patients with COVID-19 infection was as follows: COPD ( $\mathrm{n}=7 / 124 ; 5.6 \%$ ), asthma $(n=8 / 124 ; 6.5 \%)$, IBS $(n=8 / 124 ; 6.5 \%)$, diabetes $(n=3 / 124 ; 2.4 \%)$, fatty liver disease $(n=18 / 124 ; 14.5 \%)$, and high blood pressure $(n=17 / 124$; 13.7\%). The main important clinical signs and symptoms among COVID-19 positive patients were muscle aches $(n=95 / 124 ; 76.6 \%)$ lethargy $(n=$ $89 / 124 ; 71.8 \%)$, headache $(n=88 / 124 ; 71 \%)$, cough $(n=82 / 124 ; 66.1 \%)$, stuffy nose $(n=71 / 124 ; 57.2 \%)$, fever $(n=70 / 124 ; 56.4 \%)$, and sore throat $(n$ $=67 / 124 ; 54 \%)$, respectively.

\section{Detection and clinical signs of viral pathogens}

The numbers of samples found by molecular methods to be positive for influenza virus $A$, influenza virus $B$, and adenoviruses were $4.1 \%$ ( $n=6 / 145$ ), $0 \%(n=0 / 145)$, and $1.4 \%(n=2 / 145)$, respectively. The most influenza virus $A$ infection $(n=4 / 6 ; 66.7 \%)$ was seen among patients 18 to 25 years old. The influenza virus A infection was not detected among patients 26 to 30 years old. Moreover, $4.2 \%(n=3 / 71)$ of patients with BMI 18.5 to 24.9 and $5.9 \%(n=3 / 51)$ of patients with BMI 25 to 29.9 were positive for influenza virus A infection. The $66.7 \%(n=4 / 6)$ of patients who were positive for influenza virus $\mathrm{A}$ had blood group $\mathrm{O}^{+}$and all of these patients used surgical facemasks. The only underlying disease among patients who were positive for influenza virus $A$ infection was a fatty liver disease $(16.6 \% ; n=1 / 6)$. The main important clinical signs and symptoms among patients who were positive for influenza virus $A$ infection were headache $(n=4 / 6 ; 66.7 \%)$, cough $(n=4 / 6 ; 66.7 \%)$, lethargy $(n=3 / 6 ; 50 \%)$, muscle aches $(n=3 / 6 ; 50 \%)$, chest pain $(n=3 / 6 ; 50 \%)$, and dyspnea $(n=3 / 6 ; 50 \%)$, respectively.

Adenovirus infection was detected in $2.5 \%(n=2 / 81)$ of patients in $18-25$ years old. In total, $2.8 \%(n=2 / 71)$ of patients with BMI 18.5 to 24.9 were positive for adenovirus infection. Among different blood groups, adenovirus infection was seen in $9 \%(n=1 / 11)$ and $1.6 \%$ ( $n=1 / 63)$ of patients with blood groups $\mathrm{AB}^{+}$and $\mathrm{O}^{+}$, respectively. Patients with adenovirus infection are used facemasks at all times. All patients with adenovirus infection ( $\mathrm{n}=$ $2 / 2 ; 100 \%)$ showed main clinical manifestations such as cough, muscle aches, taste loss, anosmia, dyspnea, stuffy nose, and sore throat.

\section{Discussion}

In general, respiratory tract infections can be caused by different types of bacteria and viruses and presents with overlapping clinical symptoms and signs[3]. Therefore, the etiologic agents of respiratory tract infections cannot be identified by clinical signs and symptoms. Unfortunately, in most cases, physicians prescribe different antibiotics based on the patient's clinical signs. The unnecessarily prescription of antibiotics leads to the emergence of antimicrobial resistance[1]. Therefore, the rapid and accurate identification of etiologic agents of respiratory tract infections is critical for the appropriate prescription of antibiotics and suitable treatment of infection. Respiratory tract infections remain a challenge among military personnel and only limited data are available on their etiology in military soldiers[19]. The purpose of the current study was to access the bacterial (B. pertussis, $M$. pneumoniae, S. pyogenes, and H. influenzae) and viral cause (COVID-19, human influenza $A$ and $B$ viruses, and adenoviruses) of respiratory tract infections in military personnel in Tehran, Iran. In general, our analyses revealed that out of 145 patients with respiratory tract infections $43.4 \%$ and $26.7 \%$ had the $\mathrm{O}^{+}$and $\mathrm{A}^{-}$blood group, respectively. Moreover, the main clinical signs and symptoms of respiratory tract infections among all patients were muscle aches and headache, respectively. Results of our study showed that out of 145 patients with respiratory tract infections 124 (85.5\%) patients were positive to COVID-19 and 79\% of these patients had a history of close contact with COVID positive person. The main underlying disease among patients with COVID-19 infection was fatty liver disease and high blood pressure, respectively. The highest frequency of COVID-19 was seen among patients $\geq 36$ years old and BMI 30 to 34.9. In the current study, the main important clinical signs and symptoms among patients with COVID19 infection were muscle aches (76.6\%), lethargy (71.8\%), headache (71\%), cough (66.1\%), stuffy nose (57.2\%), fever (56.4\%), and sore throat (54\%), respectively. Numerous studies have surveyed the prevalence, clinical characteristics, and main underlying disease relate to COVID-19, worldwide. Results of a study performed in Italy revealed that the prevalence of COVID-19 among patients with chronic inflammatory rheumatic diseases was $4.5 \%$ [20]. Kalantari et al. surveyed the prevalence of COVID-19 with regards to the age range of patients in Tehran. They showed that $70.5 \%$ of all patients were positive for COVID-19 infection. Moreover, the results of their study showed that COVID-19 had the highest frequency among patients $>80$ years old[21]. Shakiba et al. were study the prevalence of asymptomatic COVID-19 infection in the general population. Their finding revealed that more than half (57.2\%) of patients with COVID-19 infection had no clinical symptoms[22]. On the other hand, Espinosa et al. from Spain reported that the prevalence of COVID-19 infection in hemodialysis patients was 9.2\%[23]. Results of a cross-sectional study conducted by Anand et al. revealed that the seroprevalence of COVID-19 infection was $8 \%$ in patients on dialysis in the USA[24]. Gubatan et al. were surveyed the prevalence, risk factors, and clinical outcomes of COVID-19 in patients with a history of pancreatitis. They found that the prevalence of COVID-19 in patients with prior pancreatitis was 7.8\%. Moreover, the main clinical symptoms among COVID-19 positive patients were cough, nasal congestion, dyspnea, and fever, respectively[25] In a study performed by Kashefizadeh et al., hemoptysis, diarrhea, headache, and dry cough were determined as the main clinical features of COVID-19 infection[26]. Karimi et al. revealed that $69.8 \%$ and $7 \%$ of nasopharyngeal and tear samples were positive for severe acute respiratory syndrome coronavirus 2 (SARS-CoV-2), respectively. Moreover, fever was the main clinical signs detected in $95.3 \%$ of patients[27]. Among respiratory viral pathogens, the number of samples found by molecular methods to be positive for influenza virus A was $4.1 \%(n=6 / 145)$. This result was in agreement with studies conducted by Maclntyre et al. from Australia and Malekshahi et al. from Iran[6,7]. They showed that influenza A was detected in 2.7\% and $4.9 \%$ of included patients, respectively. However, our findings were in contrast with those of Boivin et al. from Canada[28], Knobbe et al. from Senegal[1], Tang et al. from China[5], and Etemadi et al. from Iran[8]. These studies found that the prevalence of influenza A virus in patients with respiratory tract infections was $21.6 \%, 31.7 \%, 15.7 \%$, and $9.1 \%$, respectively. Influenza B virus was not detected in our study. Globally, several studies reported that the

Page 5/11 
frequency of influenza B virus in respiratory tract infections was $0 \%, 11.9 \%, 3.2 \%$, and $0.5 \%$, respectively $[8,7,5,1]$. In the present study, the prevalence of adenovirus infection among military personnel was $1.4 \%$. Moreover, among investigated bacterial pathogens, the frequency of $S$. pyogenes and $M$. pneumoniae was $2 \%(n=3 / 145)$ and $0.7 \%(n=1 / 145)$, respectively. $H$. influenzae and $B$. pertussis were not detected in the present study. In general, several studies have surveyed the prevalence of respiratory agents in military environments, worldwide. Tavakoli et al. were surveyed the molecular epidemiology of respiratory viral pathogens in military trainees. The results of their study revealed that the main clinical symptoms among patients were sore throat, rhinorrhea, cough, fever, and nasal congestion, respectively. Moreover, they showed that human rhinovirus (7.2\%), human respiratory syncytial virus A (7.2\%), and influenza B virus (6\%) bocavirus (3\%), influenza A H1N1 (2.2\%), influenza A H3N2 (1.5\%), human respiratory syncytial virus B (1.5\%), adenovirus (1.5\%), and human coronavirus $229 \mathrm{E}(0.7 \%)$ were detected among military trainees[14]. Results of a study performed in the Republic of Korea Air Force boot camp in 2011 revealed that respiratory syncytial virus (RSV) was the main causative agent of acute febrile illness in military personnel[29]. O'Shea et al. reported that the prevalence of respiratory agents among 54 British military recruits receiving basic training with respiratory symptoms were as follows: adenovirus (35\%), influenza viruses (19\%), and RSV (14\%)[30]. Heo et al. showed that among 622 soldiers with acute lower respiratory tract infections, adenovirus and influenza A viruses were found in $63.2 \%$ and $29.9 \%$, respectively[31]. The WHO declared COVID19 as a pandemic. This virus can infect individuals of all ages[32]. The peoples with underlying medical conditions such as high blood pressure, aneurism or cardiovascular disease, COPD, diabetes, and cancer are considered as susceptible groups to respiratory tract infections, especially COVID19 [33]. Moreover, due to several conditions such as stressful working environment, crowded habitation, insomnia, and demanding physical training program, military personals are considered a vulnerable group to respiratory tract infections, worldwide[19,34]. In the USA, it is revealed that $25 \%-30 \%$ of the U.S. military population were hospitalized due to respiratory infections annually[31]. Therefore, to proper decisions and control the epidemic, the implementation of several infection control strategies such as rapid diagnosis and isolation of patients, and recognizing the epidemiological features is critical in military environments.

\section{Conclusion}

In general, our results showed that among surveyed respiratory tract pathogens, the frequency of COVID-19 is very high among military personals. The low prevalence of other viral and bacterial infections among military personals in our study in comparison with the other studies conducted in different parts of the world can be attributed to the widespread outbreak of the COVID-19 disease. Our finding revealed that clinical signs and symptoms such as headache, cough, lethargy, Somatalgia, fever, and sore throat are similar and common in bacterial and viral respiratory tract infection. Therefore, the accurate detection of respiratory agents is necessary to better treatment of patients.

\section{Declarations}

\section{Ethics statements}

All methods and procedures were performed in accordance with relevant guidelines and regulations and were approved by the Institutional Ethics Committee of the AJA University of Medical Sciences (IR. AJAUMS.REC.1399.202).

\section{Consent for publication}

\section{Not applicable}

\section{Availability of data and materials}

All data generated or analyzed during this study are included in this published article.

\section{Competing interests}

The authors declare that they have no competing interests.

\section{Funding}

This research did not receive any specific grant from funding agencies in public, commercial and not-for-profit sectors.

\section{Authors' contributions}

T.A.S and S.S.M: Conceptualization; Data curation; Formal analysis; and Writing - original draft.

R.H.F, A.A, and J.R: Conceptualization; Methodology; Project administration; and Writing - original draft.

T.A.S, S.S.M, M.D, and M.Ah: Data curation; Formal analysis; Writing - original draft; and Writing - review \& editing.

T.A.S and M.A: Language editing.

S.S.M and M.Ah: Prepared Table 1. 
We would like to thank "AJA University of Medical Sciences, Tehran, Iran" for their kind cooperation.

\section{References}

1. Knobbe RB, Diallo A, Fall A, Gueye AD, Dieng A, van Immerzeel TD, Ba A, Diop A, Diop A, Niang M (2019) Pathogens causing respiratory tract infections in children less than 5 years of age in Senegal. Microbiology insights 12:1178636119890885

2. Lodes MJ, Suciu D, Wilmoth JL, Ross M, Munro S, Dix K, Bernards K, Stöver AG, Quintana M, lihoshi N (2007) Identification of upper respiratory tract pathogens using electrochemical detection on an oligonucleotide microarray. PLoS One 2 (9):e924

3. Bosch AA, Biesbroek G, Trzcinski K, Sanders EA, Bogaert D (2013) Viral and bacterial interactions in the upper respiratory tract. PLoS Pathog 9 (1):e1003057

4. Tchatchouang S, Nzouankeu A, Kenmoe S, Ngando L, Penlap V, Fonkoua M-C, Pefura-Yone E-W, Njouom R (2019) Bacterial aetiologies of lower respiratory tract infections among adults in Yaoundé, Cameroon. BioMed research international 2019

5. Tang J, Chen J, He T, Jiang Z, Zhou J, Hu B, Yang S (2019) Diversity of upper respiratory tract infections and prevalence of Streptococcus pneumoniae colonization among patients with fever and flu-like symptoms. BMC infectious diseases 19 (1):1-10

6. Maclntyre CR, Chughtai AA, Zhang Y, Seale H, Yang P, Chen J, Pan Y, Zhang D, Wang Q (2017) Viral and bacterial upper respiratory tract infection in hospital health care workers over time and association with symptoms. BMC infectious diseases 17 (1):1-9

7. Malekshahi SS, Azad TM, Yavarian J, Shahmahmoodi S, Naseri M, Rezaei F (2010) Molecular detection of respiratory viruses in clinical specimens from children with acute respiratory disease in Iran. The Pediatric infectious disease journal 29 (10):931-933

8. Etemadi MR, Othman N, Lye M-S, Ansari S, Yubbu P, Sekawi Z (2019) Diversity of respiratory viruses detected among hospitalized children with acute lower respiratory tract infections at Hospital Serdang, Malaysia. Journal of virological methods 269:1-6

9. Kannan S, Ali PSS, Sheeza A, Hemalatha K (2020) COVID-19 (Novel Coronavirus 2019)-recent trends. Eur Rev Med Pharmacol Sci 24 (4):20062011

10. Singhal T (2020) A review of coronavirus disease-2019 (COVID-19). The indian journal of pediatrics 87 (4):281-286

11. Liao S, Wang L, Ji X, Chen J, Li Q, Ma L (2019) Simultaneous detection of 15 respiratory pathogens with a fluorescence probe melting curve analysis-based multiplex real-time PCR assay. International journal of molecular epidemiology and genetics 10 (2):29

12. Sundell N, Andersson L-M, Brittain-Long R, Sundvall P-D, Alsiö Å, Lindh M, Gustavsson L, Westin J (2019) PCR detection of respiratory pathogens in asymptomatic and symptomatic adults. Journal of clinical microbiology 57 (1)

13. German V, Kopterides P, Poulikakos P, Giannakos G, Falagas ME (2008) Respiratory tract infections in a military recruit setting: a prospective cohort study. Journal of infection and public health 1 (2):101-104

14. Tavakoli A, Niya MHK, Bokharaei-Salim F, Farahmand M, Izadi M, Dorostkar R, Keyvani H (2019) The molecular epidemiology of respiratory viruses in military trainees in Iran. Medical journal of the Islamic Republic of Iran 33:40

15. Lind-Brandberg L, Welinder-Olsson C, Lagergård T, Taranger J, Trollfors B, Zackrisson G (1998) Evaluation of PCR for Diagnosis of Bordetella pertussis and Bordetella parapertussisInfections. Journal of clinical microbiology 36 (3):679-683

16. Nilsson AC, Björkman P, Persson K (2008) Polymerase chain reaction is superior to serology for the diagnosis of acute Mycoplasma pneumoniae infection and reveals a high rate of persistent infection. BMC microbiology 8 (1):1-8

17. Rigotto C, Sincero T, Simoes C, Barardi C (2005) Detection of adenoviruses in shellfish by means of conventional-PCR, nested-PCR, and integrated cell culture PCR (ICC/PCR). Water research 39 (2-3):297-304

18. Van Elden L, Nijhuis M, Schipper P, Schuurman R, Van Loon A (2001) Simultaneous detection of influenza viruses A and B using real-time quantitative PCR. Journal of clinical microbiology 39 (1):196-200

19. Sanchez JL, Cooper MJ, Myers CA, Cummings JF, Vest KG, Russell KL, Sanchez JL, Hiser MJ, Gaydos CA (2015) Respiratory infections in the US military: recent experience and control. Clinical microbiology reviews 28 (3):743-800

20. Quartuccio L, Valent F, Pasut E, Tascini C, De Vita S (2020) Prevalence of COVID-19 among patients with chronic inflammatory rheumatic diseases treated with biologic agents or small molecules: a population-based study in the first two months of COVID-19 outbreak in Italy. Joint Bone Spine 87 (5):439-443

21. Kalantari H, Tabrizi AHH, Foroohi F (2020) Determination of COVID-19 prevalence with regards to age range of patients referring to the hospitals located in western Tehran, Iran. Gene reports 21:100910

22. Shakiba M, Nazemipour M, Heidarzadeh A, Mansournia M (2020) Prevalence of asymptomatic COVID-19 infection using a seroepidemiological survey. Epidemiology \& Infection:1-7

23. Rodríguez-Espinosa D, Broseta JJ, Cuadrado E, Maduell F (2020) Prevalence of COVID-19 infection in hemodialysis patients detected using serologic screening. Journal of the American Society of Nephrology 31 (12):2966-2967

24. Anand S, Montez-Rath M, Han J, Bozeman J, Kerschmann R, Beyer P, Parsonnet J, Chertow GM (2020) Prevalence of SARS-CoV-2 antibodies in a large nationwide sample of patients on dialysis in the USA: a cross-sectional study. The Lancet 396 (10259):1335-1344

Page $7 / 11$ 
25. Gubatan J, Levitte S, Patel A, Balabanis T, Sharma A, Jones E, Lee B, Manohar M, Swaminathan G, Park W (2021) Prevalence, risk factors and clinical outcomes of COVID-19 in patients with a history of pancreatitis in Northern California. Gut 70 (2):440-441

26. Kashefizadeh A, Ohadi L, Golmohammadi M, Araghi F, Dadkhahfar S, Kiani A, Abedini A, Fadaii A, Ghojoghi A, Nouraie M (2020) Clinical features and short-term outcomes of COVID-19 in Tehran, Iran: An analysis of mortality and hospital stay. Acta Bio-medica: Atenei Parmensis 91

(4):e2020147-e2020147

27. Karimi S, Arabi A, Shahraki T, Safi S (2020) Detection of severe acute respiratory syndrome Coronavirus-2 in the tears of patients with Coronavirus disease 2019. Eye 34 (7):1220-1223

28. Boivin G, Côté S, Déry P, De Serres G, Bergeron MG (2004) Multiplex real-time PCR assay for detection of influenza and human respiratory syncytial viruses. Journal of clinical Microbiology $42(1): 45-51$

29. Park W-J, Yoo S-J, Lee S-H, Chung J-W, Jang K-H, Moon J-D (2015) Respiratory syncytial virus outbreak in the basic military training cAMP of the republic of Korea Air Force. Journal of Preventive Medicine and Public Health 48 (1):10

30. O'Shea MK, Pipkin C, Cane PA, Gray GC (2007) Respiratory syncytial virus: an important cause of acute respiratory illness among young adults undergoing military training. Influenza and other respiratory viruses 1 (5-6):193-197

31. Heo JY, Lee JE, Kim HK, Choe K-W (2014) Acute lower respiratory tract infections in soldiers, South Korea, April 2011-March 2012. Emerging infectious diseases 20 (5):875

32. Chaibakhsh S, Pourhoseingholi A, Vahedi M (2020) Global incidence and mortality rate of covid-19; Special focus on Iran, Italy and China. Archives of Iranian medicine 23 (7):455-461

33. Dadar M, Fakhri Y, Bjørklund G, Shahali Y (2020) The association between the incidence of COVID-19 and the distance from the virus epicenter in Iran. Archives of virology 165 (11):2555-2560

34. Korzeniewski K, Nitsch-Osuch A, Konior M, Lass A (2015) Respiratory tract infections in the military environment. Respiratory physiology \& neurobiology 209:76-80

\section{Tables}

Table 1. Demographic information of military personnel with prevalence and clinical signs of respiratory tract infections among these patients. 


\begin{tabular}{|c|c|c|c|c|c|c|c|c|c|c|}
\hline Characteristic & No. & $\begin{array}{l}\text { Total with } \\
\text { characteristic } \\
\mathrm{N}(\%)\end{array}$ & $\begin{array}{l}\text { With } \\
\text { COVID- } \\
19 \\
N(\%)\end{array}$ & $\begin{array}{l}\begin{array}{l}\text { With } \\
\text { Influenza } \\
\text { A }\end{array} \\
\mathrm{N}(\%)\end{array}$ & $\begin{array}{l}\text { With } \\
\text { Influenza } \\
\text { B } \\
N(\%)\end{array}$ & $\begin{array}{l}\text { With } \\
\text { Pertussis } \\
\text { N (\%) }\end{array}$ & $\begin{array}{l}\text { With } \\
\text { Mycoplasma } \\
\mathrm{N}(\%)\end{array}$ & $\begin{array}{l}\text { With } \\
\text { Adeno } \\
\mathrm{N}(\%)\end{array}$ & $\begin{array}{l}\text { With } \\
\text { Pyogenesis }\end{array}$ & $\begin{array}{l}\text { With } \\
\text { Haemophilus }\end{array}$ \\
\hline \multicolumn{11}{|l|}{ Age } \\
\hline $18-25$ years & 145 & 81 (55.9\%) & $\begin{array}{l}63 \\
(77.8 \%)\end{array}$ & $4(4.9 \%)$ & $0(0 \%)$ & $0(0 \%)$ & $1(1.25 \%)$ & $\begin{array}{l}2 \\
(2.5 \%)\end{array}$ & $3(3.7 \%)$ & $0(0 \%)$ \\
\hline $26-30$ years & 145 & $24(16.6 \%)$ & $\begin{array}{l}23 \\
(95.8 \%)\end{array}$ & $0(0 \%)$ & $0(0 \%)$ & $0(0 \%)$ & $0(0 \%)$ & $0(0 \%)$ & $0(0 \%)$ & $0(0 \%)$ \\
\hline $31-35$ years & 145 & $11(7.6 \%)$ & $\begin{array}{l}10 \\
(90.1 \%)\end{array}$ & $1(9 \%)$ & $0(0 \%)$ & $0(0 \%)$ & $0(0 \%)$ & $0(0 \%)$ & $0(0 \%)$ & $0(0 \%)$ \\
\hline$>=36$ & 145 & $29(20 \%)$ & $\begin{array}{l}28 \\
(96.5 \%)\end{array}$ & $1(3.4 \%)$ & $0(0 \%)$ & $0(0 \%)$ & $0(0 \%)$ & $0(0 \%)$ & $0(0 \%)$ & $0(0 \%)$ \\
\hline \multicolumn{11}{|l|}{ BMI } \\
\hline$<18.5$ & 145 & $4(2.8 \%)$ & $3(75 \%)$ & $0(0 \%)$ & $0(0 \%)$ & $0(0 \%)$ & $0(0 \%)$ & $0(0 \%)$ & $0(0 \%)$ & $0(0 \%)$ \\
\hline $18.5-24.9$ & 145 & 71 (49\%) & $\begin{array}{l}59 \\
(83 \%)\end{array}$ & $3(4.2 \%)$ & $0(0 \%)$ & $0(0 \%)$ & $0(0 \%)$ & $\begin{array}{l}2 \\
(2.8 \%)\end{array}$ & $1(1.4 \%)$ & $0(0 \%)$ \\
\hline $25-29.9$ & 145 & $51(35.2 \%)$ & $\begin{array}{l}45 \\
(88.2 \%)\end{array}$ & $3(5.9 \%)$ & $0(0 \%)$ & $0(0 \%)$ & $0(0 \%)$ & $0(0 \%)$ & $1(2 \%)$ & $0(0 \%)$ \\
\hline $30-34.9$ & 145 & 18 (12.4\%) & $\begin{array}{l}17 \\
(94.5 \%)\end{array}$ & $0(0 \%)$ & $0(0 \%)$ & $0(0 \%)$ & $0(0 \%)$ & $0(0 \%)$ & $1(5.6 \%)$ & $0(0 \%)$ \\
\hline $35-39.9$ & 145 & $0(0 \%)$ & $0(0 \%)$ & $0(0 \%)$ & $0(0 \%)$ & $0(0 \%)$ & $0(0 \%)$ & $0(0 \%)$ & $0(0 \%)$ & $0(0 \%)$ \\
\hline$>40$ & 145 & $1(7 \%)$ & $0(0 \%)$ & $0(0 \%)$ & $0(0 \%)$ & $0(0 \%)$ & $1(100 \%)$ & $0(0 \%)$ & $0(0 \%)$ & $0(0 \%)$ \\
\hline \multicolumn{11}{|l|}{ Blood groups } \\
\hline$O^{+}$ & 145 & $63(43.4 \%)$ & $\begin{array}{l}51 \\
(81 \%)\end{array}$ & $4(6.3 \%)$ & $0(0 \%)$ & $0(0 \%)$ & $0(0 \%)$ & $\begin{array}{l}1 \\
(1.6 \%)\end{array}$ & $3(4.8 \%)$ & $0(0 \%)$ \\
\hline$\sigma$ & 145 & $3(2.1 \%)$ & $\begin{array}{l}3 \\
(100 \%)\end{array}$ & $0(0 \%)$ & $0(0 \%)$ & $0(0 \%)$ & $0(0 \%)$ & $0(0 \%)$ & $0(0 \%)$ & $0(0 \%)$ \\
\hline $\mathrm{A}^{+}$ & 145 & $40(27.6 \%)$ & $\begin{array}{l}35 \\
(87.5 \%)\end{array}$ & $1(2.5 \%)$ & $0(0 \%)$ & $0(0 \%)$ & $0(0 \%)$ & $0(0 \%)$ & $0(0 \%)$ & $0(0 \%)$ \\
\hline$A^{-}$ & 145 & $3(2.1 \%)$ & $\begin{array}{l}3 \\
(100 \%)\end{array}$ & $0(0 \%)$ & $0(0 \%)$ & $0(0 \%)$ & $0(0 \%)$ & $0(0 \%)$ & $0(0 \%)$ & $0(0 \%)$ \\
\hline $\mathrm{B}^{+}$ & 145 & $21(14.5 \%)$ & $\begin{array}{l}20 \\
(95.2 \%)\end{array}$ & $1(4.8 \%)$ & $0(0 \%)$ & $0(0 \%)$ & $0(0 \%)$ & $0(0 \%)$ & $0(0 \%)$ & $0(0 \%)$ \\
\hline $\mathrm{B}^{-}$ & 145 & $4(2.8 \%)$ & $3(75 \%)$ & $0(0 \%)$ & $0(0 \%)$ & $0(0 \%)$ & $1(25 \%)$ & $0(0 \%)$ & $0(0 \%)$ & $0(0 \%)$ \\
\hline $\mathrm{AB}^{+}$ & 145 & $11(7.6 \%)$ & $9(82 \%)$ & $0(0 \%)$ & $0(0 \%)$ & $0(0 \%)$ & $0(0 \%)$ & $1(9 \%)$ & $0(0 \%)$ & $0(0 \%)$ \\
\hline$A B^{-}$ & 145 & $0(0 \%)$ & $0(0 \%)$ & $0(0 \%)$ & $0(0 \%)$ & $0(0 \%)$ & $0(0 \%)$ & $0(0 \%)$ & $0(0 \%)$ & $0(0 \%)$ \\
\hline $\begin{array}{l}\text { The use of } \\
\text { facemasks } \\
\text { during COVID- } \\
19\end{array}$ & 145 & $145(100 \%)$ & $\begin{array}{l}124 \\
(85.5 \%)\end{array}$ & $6(4.1 \%)$ & $0(0 \%)$ & $0(0 \%)$ & $1(0.7 \%)$ & $\begin{array}{l}2 \\
(1.4 \%)\end{array}$ & $3(2 \%)$ & $0(0 \%)$ \\
\hline \multicolumn{11}{|c|}{ Types of facemasks } \\
\hline Cloth facemask & 145 & $17(11.7 \%)$ & $\begin{array}{l}13 \\
(76.5 \%)\end{array}$ & $0(0 \%)$ & $0(0 \%)$ & $0(0 \%)$ & $0(0 \%)$ & $\begin{array}{l}1 \\
(5.9 \%)\end{array}$ & $1(5.9 \%)$ & $0(0 \%)$ \\
\hline $\begin{array}{l}\text { Surgery } \\
\text { facemask }\end{array}$ & 145 & $123(84.8 \%)$ & $\begin{array}{l}106 \\
(86.2 \%)\end{array}$ & $6(4.9 \%)$ & $0(0 \%)$ & $0(0 \%)$ & $1(0.8 \%)$ & $\begin{array}{l}1 \\
(0.8 \%)\end{array}$ & $2(1.6 \%)$ & $0(0 \%)$ \\
\hline $\begin{array}{l}\mathrm{N} 95 \text { or FFP2 } \\
\text { facemasks }\end{array}$ & 145 & $5(3.4 \%)$ & $\begin{array}{l}5 \\
(100 \%)\end{array}$ & $0(0 \%)$ & $0(0 \%)$ & $0(0 \%)$ & $0(0 \%)$ & $0(0 \%)$ & $0(0 \%)$ & $0(0 \%)$ \\
\hline \multicolumn{11}{|c|}{ Duration of facemask use } \\
\hline All time & 145 & $104(71.7 \%)$ & $\begin{array}{l}90 \\
(86.5 \%)\end{array}$ & $3(2.9 \%)$ & $0(0 \%)$ & $0(0 \%)$ & $1(0.96 \%)$ & $\begin{array}{l}2 \\
(1.9 \%)\end{array}$ & $2(1.9 \%)$ & $0(0 \%)$ \\
\hline Some times & 145 & $32(22.1 \%)$ & $\begin{array}{l}25 \\
(78.1 \%)\end{array}$ & $3(9.4 \%)$ & $0(0 \%)$ & $0(0 \%)$ & $0(0 \%)$ & $0(0 \%)$ & $1(3.1 \%)$ & $0(0 \%)$ \\
\hline
\end{tabular}




\begin{tabular}{|c|c|c|c|c|c|c|c|c|c|c|}
\hline Rarely & 145 & $9(6.2 \%)$ & $\begin{array}{l}9 \\
(100 \%)\end{array}$ & $0(0 \%)$ & $0(0 \%)$ & $0(0 \%)$ & $0(0 \%)$ & $0(0 \%)$ & $0(0 \%)$ & $0(0 \%)$ \\
\hline COPD & 145 & $7(4.8 \%)$ & $\begin{array}{l}7 \\
(100 \%)\end{array}$ & $0(0 \%)$ & $0(0 \%)$ & $0(0 \%)$ & $0(0 \%)$ & $0(0 \%)$ & $0(0 \%)$ & $0(0 \%)$ \\
\hline Asthma & 145 & $10(6.9 \%)$ & $8(80 \%)$ & $0(0 \%)$ & $0(0 \%)$ & $0(0 \%)$ & $0(0 \%)$ & $0(0 \%)$ & $0(0 \%)$ & $0(0 \%)$ \\
\hline Sore throat & 145 & 77 (53.1\%) & $\begin{array}{l}67 \\
(87 \%)\end{array}$ & $2(2.6 \%)$ & $0(0 \%)$ & $0(0 \%)$ & $0(0 \%)$ & $\begin{array}{l}2 \\
(2.6 \%)\end{array}$ & $2(2.6 \%)$ & $0(0 \%)$ \\
\hline Stuffy nose & 145 & $82(56.6 \%)$ & $\begin{array}{l}71 \\
(86.6 \%)\end{array}$ & $1(1.2 \%)$ & $0(0 \%)$ & $0(0 \%)$ & $0(0 \%)$ & $\begin{array}{l}2 \\
(2.4 \%)\end{array}$ & $1(1.2 \%)$ & $0(0 \%)$ \\
\hline IBS & 145 & $10(6.9 \%)$ & $8(80 \%)$ & $2(20 \%)$ & $0(0 \%)$ & $0(0 \%)$ & $0(0 \%)$ & $0(0 \%)$ & $0(0 \%)$ & $0(0 \%)$ \\
\hline Nausea & 145 & 19 (13.1\%) & $\begin{array}{l}17 \\
(89.5 \%)\end{array}$ & $0(0 \%)$ & $0(0 \%)$ & $0(0 \%)$ & $0(0 \%)$ & $0(0 \%)$ & $0(0 \%)$ & $0(0 \%)$ \\
\hline Vomiting & 145 & $33(22.8 \%)$ & $\begin{array}{l}27 \\
(82 \%)\end{array}$ & $0(0 \%)$ & $0(0 \%)$ & $0(0 \%)$ & $0(0 \%)$ & $0(0 \%)$ & $0(0 \%)$ & $0(0 \%)$ \\
\hline Diabetes & 145 & $3(2.1 \%)$ & $\begin{array}{l}3 \\
(100 \%)\end{array}$ & $0(0 \%)$ & $0(0 \%)$ & $0(0 \%)$ & $0(0 \%)$ & $0(0 \%)$ & $0(0 \%)$ & $0(0 \%)$ \\
\hline Red eyes & 145 & $42(29 \%)$ & $\begin{array}{l}38 \\
(90.5 \%)\end{array}$ & $1(2.4 \%)$ & $0(0 \%)$ & $0(0 \%)$ & $0(0 \%)$ & $0(0 \%)$ & $1(2.4 \%)$ & $0(0 \%)$ \\
\hline Headache & 145 & 102 (70.3\%) & $\begin{array}{l}88 \\
(86.3 \%)\end{array}$ & $4(3.9 \%)$ & $0(0 \%)$ & $0(0 \%)$ & $1(1 \%)$ & $2(2 \%)$ & $1(1 \%)$ & $0(0 \%)$ \\
\hline $\begin{array}{l}\text { Fatty } \\
\text { liver disease }\end{array}$ & 145 & $20(13.8 \%)$ & $\begin{array}{l}18 \\
(90 \%)\end{array}$ & $1(5 \%)$ & $0(0 \%)$ & $0(0 \%)$ & $0(0 \%)$ & $0(0 \%)$ & $0(0 \%)$ & $0(0 \%)$ \\
\hline Diarrhea & 145 & $45(31 \%)$ & $\begin{array}{l}39 \\
(86.7 \%)\end{array}$ & $0(0 \%)$ & $0(0 \%)$ & $0(0 \%)$ & $0(0 \%)$ & $\begin{array}{l}1 \\
(2.2 \%)\end{array}$ & $0(0 \%)$ & $0(0 \%)$ \\
\hline $\begin{array}{l}\text { Gastrointestinal } \\
\text { (GI) bleeding }\end{array}$ & 145 & $2(1.4 \%)$ & $\begin{array}{l}2 \\
(100 \%)\end{array}$ & $0(0 \%)$ & $0(0 \%)$ & $0(0 \%)$ & $0(0 \%)$ & $0(0 \%)$ & $0(0 \%)$ & $0(0 \%)$ \\
\hline $\begin{array}{l}\text { Contact with } \\
\text { COVID -19 } \\
\text { positive person }\end{array}$ & 145 & 115 (79.3\%) & $\begin{array}{l}98 \\
(85.2 \%)\end{array}$ & $4(3.5 \%)$ & $0(0 \%)$ & $0(0 \%)$ & $0(0 \%)$ & $\begin{array}{l}1 \\
(0.9 \%)\end{array}$ & $3(2.6 \%)$ & $0(0 \%)$ \\
\hline Dyspnea & 145 & $51(35.2 \%)$ & $\begin{array}{l}42 \\
(82.3 \%)\end{array}$ & $3(5.9 \%)$ & $0(0 \%)$ & $0(0 \%)$ & $0(0 \%)$ & $\begin{array}{l}2 \\
(3.9 \%)\end{array}$ & $0(0 \%)$ & $0(0 \%)$ \\
\hline Chest pain & 145 & $57(39.3 \%)$ & $\begin{array}{l}48 \\
(84.2 \%)\end{array}$ & $1(1.7 \%)$ & $0(0 \%)$ & $0(0 \%)$ & $1(1.8 \%)$ & $0(0 \%)$ & $2(3.5 \%)$ & $0(0 \%)$ \\
\hline Smoking & 145 & 47 (32.4\%) & $\begin{array}{l}41 \\
(87.2 \%)\end{array}$ & $2(4.2 \%)$ & $0(0 \%)$ & $0(0 \%)$ & $0(0 \%)$ & $\begin{array}{l}1 \\
(2.1 \%)\end{array}$ & $1(2.1 \%)$ & $0(0 \%)$ \\
\hline Anosmia & 145 & $62(42.8 \%)$ & $\begin{array}{l}53 \\
(85.5 \%)\end{array}$ & $2(3.2 \%)$ & $0(0 \%)$ & $0(0 \%)$ & $0(0 \%)$ & $\begin{array}{l}2 \\
(3.2 \%)\end{array}$ & $1(1.6 \%)$ & $0(0 \%)$ \\
\hline Taste loss & 145 & 52 (35.9\%) & $\begin{array}{l}44 \\
(84.6 \%)\end{array}$ & $1(1.9 \%)$ & $0(0 \%)$ & $0(0 \%)$ & $0(0 \%)$ & $\begin{array}{l}2 \\
(3.8 \%)\end{array}$ & $1(1.9 \%)$ & $0(0 \%)$ \\
\hline $\begin{array}{l}\text { Alcohol } \\
\text { consumption }\end{array}$ & 145 & 19 (13.1\%) & $\begin{array}{l}18 \\
(94.7 \%)\end{array}$ & $1(5.3 \%)$ & $0(0 \%)$ & $0(0 \%)$ & $0(0 \%)$ & $0(0 \%)$ & $0(0 \%)$ & $0(0 \%)$ \\
\hline $\begin{array}{l}\text { Loss of } \\
\text { consciousness }\end{array}$ & 145 & $5(3.4 \%)$ & $\begin{array}{l}5 \\
(100 \%)\end{array}$ & $0(0 \%)$ & $0(0 \%)$ & $0(0 \%)$ & $0(0 \%)$ & $0(0 \%)$ & $0(0 \%)$ & $0(0 \%)$ \\
\hline Joint pain & 145 & $67(46.2 \%)$ & $\begin{array}{l}60 \\
(89.5 \%)\end{array}$ & $1(1.5 \%)$ & $0(0 \%)$ & $0(0 \%)$ & $0(0 \%)$ & $\begin{array}{l}1 \\
(1.5 \%)\end{array}$ & $1(1.5 \%)$ & $0(0 \%)$ \\
\hline Fever & 145 & 78 (53.8\%) & $\begin{array}{l}70 \\
(89.7 \%)\end{array}$ & $2(2.6 \%)$ & $0(0 \%)$ & $0(0 \%)$ & $0(0 \%)$ & $\begin{array}{l}1 \\
(1.3 \%)\end{array}$ & $2(2.6 \%)$ & $0(0 \%)$ \\
\hline Chills & 145 & $63(43.4 \%)$ & $\begin{array}{l}57 \\
(90.5 \%)\end{array}$ & $1(1.6 \%)$ & $0(0 \%)$ & $0(0 \%)$ & $0(0 \%)$ & $\begin{array}{l}1 \\
(1.6 \%)\end{array}$ & $0(0 \%)$ & $0(0 \%)$ \\
\hline Muscle aches & 145 & 110 (75.9\%) & $\begin{array}{l}95 \\
(86.4 \%)\end{array}$ & 3 (2.7\%) & $0(0 \%)$ & $0(0 \%)$ & $1(0.9 \%)$ & $\begin{array}{l}2 \\
(1.8 \%)\end{array}$ & $2(1.8 \%)$ & $0(0 \%)$ \\
\hline Lethargy & 145 & 100 (69\%) & $\begin{array}{l}89 \\
(89 \%)\end{array}$ & $3(3 \%)$ & $0(0 \%)$ & $0(0 \%)$ & $0(0 \%)$ & $1(1 \%)$ & $2(2 \%)$ & $0(0 \%)$ \\
\hline Cough & 145 & $96(66.2 \%)$ & $\begin{array}{l}82 \\
(85.4 \%)\end{array}$ & $4(4.2 \%)$ & $0(0 \%)$ & $0(0 \%)$ & $0(0 \%)$ & $\begin{array}{l}2 \\
(2.1 \%)\end{array}$ & $2(2.1 \%)$ & $0(0 \%)$ \\
\hline High blood & 145 & $17(11.7 \%)$ & 17 & $0(0 \%)$ & $0(0 \%)$ & $0(0 \%)$ & $0(0 \%)$ & $0(0 \%)$ & $0(0 \%)$ & $0(0 \%)$ \\
\hline
\end{tabular}


Page 11/11 